\section{MARCH 2004}

- The Species at Risk: Pathways to Recovery Conference, 2-6 March. Victoria, B.C. Canada. Contact: Patrick Daigle, RPF: Fax: 250-356-9145; patrick.daigle@gems3.gov.bc.ca; www. speciesatrisk2004.ca

- World of Wood, 17-19 March. Orlando, Florida, USA. Contact: Fax: 703-820-8550; infor@ipawood.org; www.iwpawood.org/convention.html

- Wood Technology Clinic and Show, 17-19 March.

Portland, Oregon. Contact: Kathy Porter: Fax: 770-956-7938; kporter@mfi.com

- Human Dimensions of Family and Farm Forestry International Symposium, 29 March-1 April.

Washington State University, Contact: familyforestry@wsu.edu; www.familyforestrysymposium.wsu.edu

- AusTimber 2004, 29 March-3 April. Albury, NSW Australia. Contact: www.austimber2004.com

-17th Annual Global Forest Industry Conference, 31 March.

Vancouver, BC. Contact: Angie Dosanjh, PricewaterhouseCoopers; angie.dosanjh@ca.pwc.com

\section{APRIL 2004}

- Management of Tropical Dry Forest Woodlands and Savanas-Assessment, Silviculture, and Scenarios (IUFRO), 12-14 April.

Brasilia, Brazil. Contact: Prof. Jose Imana Encinas: Fax: 55-61-347-0631; imana@ guarany.edp.unb.br

- 3rd International Symposium on Sustainable Management of Forest Resources- SIMFOR 2004, 21-23 April. Pinar del Rio, Cuba. Contact: C. Fernando Hernandez Martinez; Fax: 82-77-9353; fhernandez@af.upr.edu.cu

- FOREXPO 2004, The European Forestry and Forest Management Trade Fair, 21-24 April.

Mimizan, France. Contact: Fax: 33-5-5681-78-98; info@forexpo.fr; www.forexpo.fr

- The Boreal Forest, Building Strong Communities. 47th Annual General Meeting, Ontario Professional Foresters Association (Guest Speaker, Rex Murphy, host of CBC's Cross Country Checkup), 28-30 April. Thunder Bay, Ontario. Contact: OPFA, Tel: 705-436-
2226; Fax: 705-436-1151; opfa@on.aibn. com; www.opfa.on.ca

\section{MAY 2004}

- Northbound to Superior-Protecting Ontario's Nature: 73rd Annual General Meeting and Gathering, 29 May. Toronto, Ontario. Contact: Tel: 1-800440-2366; Fax: 416-444-9866; info@ontarionature.org; www.ontarionature.org

- International Conference on Economics of Sustainable Forest Management (IUFRO), 20-22 May.

Toronto, Canada. Contact: Shashi Kant, Fax: 416-978-3834; e-mail: shashi.kant@ utoronto.ca

- Urban Woods for People followed by 7th IUFRO European Forum on Urban Forestry (IUFRO), 23-27 May. Stockholm, Sweden. Contact: Cecil C. Konijnendijk, cck@fsl.dk

\section{JUNE 2004}

8th International Timber Tradeshow for Professionals in the wood industry, 2-4 June.

Nantes, France. Contact: Samantha Padden: Fax: 011.33240730301 ; sam@timbershow.com; www.timbershow.com

- 1st World Congress of Agroforestry: Working Together for Sustainable Land-use Systems. 27 June-2 July.

Orlando, Florida, USA. Contact: Mandy Padgett: mrpadgett@mail.ifas.ufl.edu; http://conference.ifas.ufl.edu/wca

- The Evaluation of Forest Policies and Programmes, 27 June-3 July.

Epinal, Vosges, France. Contact: Brita Pajari, European Forest Institute: brita.pajari@efi.fi

\section{JULY 2004}

- 36th Session of the International Tropical Timber Council, 20-23 July. Switzerland. Contact: Collins Ahadome: Fax: 81-45-223-1111; itto@itto.orjp; www.itto.or.jp

- 7th INTECOL International Wetlands Conference, 25-31 July.

Utrecht, The Netherlands. Contact: congresbureau2@fbu.uu.nl; www.bio.uu.nl/ intecol

- Forest Genetics and Climate Change (IUFRO), 26-29 July.

Vernon, BC. Canada. Contact: Alvin Yanchuk, Fax: 250-387-0046; Alvin Yanchuk@gems4.gov.bc.ca
AUGUST 2004

$\checkmark$ Forest Diversity and Resistance to Native and Exotic Pest Insects (IUFRO), 15-20 August.

Hammer Springs, New Zealand. Contact: Andrew Liebhold; Fax: 304-285-1505, aliebhold@fs.fed.us; http://iufro.boku. ac.at/iufro

- International Congress of Entomology, 15-21 August.

Brisbane, Australia. Contact: Ashley Gordon, Congress Director: Ashley@ ccm.com.au; www.ccm.com.au/icoe/

11th International Conference on Root and Butt Rots (IUFRO), 16-22 August.

Poznan-Bialowieza, Poland. Contact: Malgorzata Manka, Fax: 4861-848-77-11; mmanka@owl.au.poznan.pl

- 13th International Symposium on Inventories, 22-27 August.

Budapest, Hungary. Contact: chikana@ axelero.hu; www.isir.hu

\section{SEPTEMBER 2004}

- The Use of Vegetation to Improve Slope Stability (IUFRO), 6-10 September. Thessaloniki, Greece. Contact: Sanna Dupuy: Fax:33-5-566-80713; ecoconf@irbb3.pierroton.inra.fr

- Regenerating Mountain Forests, 12-16 September.

Kloster Seeon, Bavaria. Contact: Dr. Peter Brang: Fax: 41 (0) 173922 15; www.forst.tu-muenchen.de/ext/lst/waldb/ iufro/index_en.html

- DEMO International 2004, 16-18 September

Quebec City, Quebec, Canada. Contact: Anne Sawyer, Canadian Woodlands Forum; Tel: 514-392-6947; asawyer@cwfcof.org

$\checkmark$ Unifying Knowledge for Sustainability in the Western Hemisphere, 20-24 September.

Denver, Colorado. Contact: Tel: 303830-6850; info@monitoringsymposium.com; www.monitoringsymposium.com/index.cfm

- The Economics and Management of High Productivity Plantations, 27-30 September.

Lugo, Spain. Contact: Dr. Juan Gabriel Alvarez: algonjg@lugo.usc.es 
OCTOBER 2004

- New Tools for the Urban Forestry Toolbox: 6th Canadian Urban Forest Conference (CUFC), October (12-14).

Kelowna, BC. Contacts: Christian Walli, 6th Canadian Urban Forest Conference, tel.604-521-7771; christian_walli@ brinkman.ca; Michael Rosen, Tree Canada Foundation, tel. 613-567-5545; mrosen@treecanada.ca

- The Canadian Institute of Forestry/ Institut forestier du Canada and the Society of American Foresters Joint 2004 Annual General Meeting and Convention, "One Forest Under Two Flags/Une forêt sous deux drapeaux", 2-6 October.

Edmonton, Alberta Canada. CIF/IFC Local Contact: Teresa Stokes, Tel: 780422-5203; Fax: 780-427-0084; teresa.stokes@gov.ab.ca; www.cif-ifc.org

\section{NOVEMBER 2004}

- PAP- FOR RUSSIA 2004 (8th Inter. Exhib. and Conference for Russia's Paper, Pulp and Forestry Industries), 23-26 November.

St. Petersburg, Russia. Contact: Sharon Deutch, Tel: 301-493-5500, ext. 3304; deutch@ejkrause.com

\section{FEBRUARY 2005}

17th Commonwealth Forestry Conference, 28 February-5 March.

Colombo, Sri Lanka Contact: Libby Jones: Fax: 44-0-131-314-6137; libby. jones@forestry.gsi.gov.uk

\section{MARCH 2005}

- CONEXPO-CON/AGG 2005 and IFPE2005, 15-19 March.

Las Vegas, Nevada. Contact: Tel: $301-$ 587-3140; www.conexpoconagg.com

\section{AUGUST 2005}

- XXII IUFRO World Congress, Forests in the Balance: Linking Tradition and Technology, 8-13 August. Brisbane, Australia. Contact: Russell J. Haines, Queensland Forestry Research Institute: Fax: 61-7-389-69714; hainesr@ qfril.se2.dpi.gld.gov.au; http://iufro. boku.ac.at/iufro

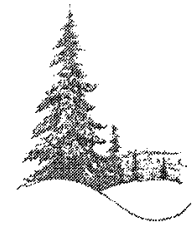

\section{CIF/IFC}

NATIONAL

AWARDS

\section{Nominate a colleague for one of CIF/IFC's national awards.}

The Canadian Institute of Forestry/Institut forestier du Canada recognizes through a national awards program the outstanding contributions made to Forestry by members and non-members.

\section{National Awards}

Canadian Forestry Achievement Award - recognizes outstanding achievement in forestry in Canada.

Canadian Forestry Scientific Achievement Award - recognizes outstanding achievement in forestry research in Canada.

International Forestry Achievement Award - recognizes outstanding achievement in international forestry.

James M. Kitz Award - recognizes the contributions of those newer to the profession.

Canadian Forest Management Group Achievement Award - recognizes outstanding achievement by teams and groups of Natural Resource managers, Researchers and NGO groups in the field of forest resources related activities in Canada.

Tree of Life Award - recognizes individuals who have made superior, dedicated or particularly effective contributions to sustainable forest resource management, forest renewal or sustained yield integrated management of the forest and its intrinsic resources.

Nomination deadline for 2004 CIF/IFC National Awards is May 1, 2004

Award criteria and nomination information may be obtained from the CIF/IFC web site - http://www.cif-ifc.org, CIF/IFC's national office 151 Slater Street, Suite 606, Ottawa, Ontario K1P 5H3

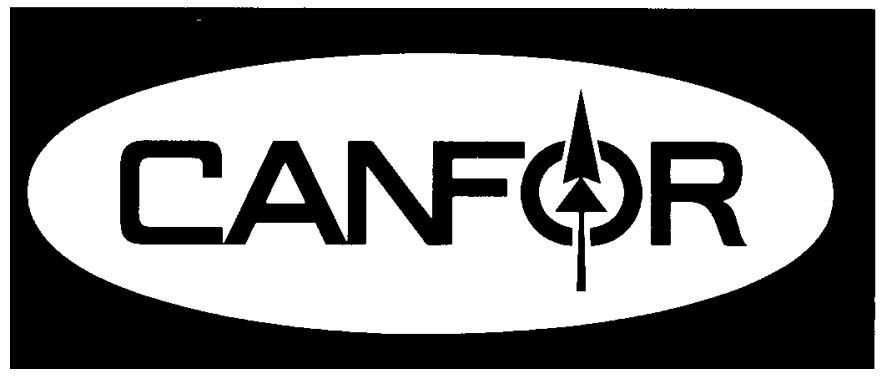

A CIF/IFC Corporate Sustaining Member 